\title{
A CIGÁNYSÁG KÉPÉNEK VÁLTOZÁSAI A HARMINCÉVES EDUCATIÓ-BAN
}

\author{
FORRAY R. KATALIN \\ Pécsi Tudományegyetem
}

Beérkezett: 2021. február 21., elfogadva: 2021, október 12.

A tanulmány a cigány, roma népesség oktatási helyzetét mutatja be a rendszerváltás óta eltelt időszakban. Áttekinti a kisebbségi törvény eredményeit és korrekcióját, a magyarországi cigányok által beszélt nyelvek, a romani és beás nyelvek bevonását a hivatalosan elismert nyelvek közé. Hangsúlyozza a Gandhi Gimnázium és a Pécsi Tudományegyetemen megvalósult Romológia Tanszék fontosságát. A cigány, roma népesség túlnyomó többsége ugyan ma is alacsony iskolázottságú, ám vannak olyan térségek, ahol jelentős eredmények születtek. Az iskolázottsági szint emelésére irányuló kormányzati, egyházi és civil erőfeszítések eredményei lassan megmutatkoznak.

Kulcsszavakः cigány/roma, romani/beás nyelv, cigány/roma iskolázottság, felzárkóztatás

The study reviews policies related to the education of the Roma population and their outcomes since the change of regime. It presents the Minority Law and its subsequent amendments to the schooling of Romani and Beas languages. He emphasizes the importance of Gandhi High School and the Department of Romology of the University of Pécs. It characterizes the low level of education of the Roma population by presenting case studies. Finally, it describes the possibilities of support by describing two helpful interventions. Most importantly, that the extreme backwardness of the Roma, previously considered general, has declined significantly.

Keywords: Romani population in Hungary, Romani languages, schooling, programmes for undereducated

\section{Bevezetés}

\section{$\mathrm{A}$ rendszerváltást követő évben, mint korábban is nemegyszer, egy kisvárosi is- kolába hívtak meg előadást tartani, beszélgetni. Az iskola súlyos problémával szembesült. Az egykor elit leányiskola épületében müködő általános iskoláról}


a város vezetése úgy döntött, hogy ide kell beiskolázni a közeli cigánytelep gyermekeit. Az új beiskolázás hírére a nem cigány családok a város központi iskolájába íratták át gyermekeiket. Itt pedig a tanárok olyan helyzetbe kerültek, hogy megbélyegzett „cigányiskolában” kell a jövőben tanítaniuk, új állást sem tudnak majd kapni, mert „cigányiskolából” érkeznek. Miért érzik magukat (is) megbélyegzetteknek? „Ludas ebben a két évtizedes propaganda is, amely kilátástalan pesszimizmust sulykol: a cigányság egésze olyan elesett, önmagán segíteni nem képes népcsoport, amelyért áldozatot kell hozni" - írtam a beszámolóban. A rövid írást nem merték megjelentetni a pedagógiai lapok, amelyeknek elküldtem. Az Educatio föszerkesztője mosolyogva mondta, add csak ide nekünk. Így az 1992. évi 2. számában megjelenhetett a beszámoló a Szabadság piaci ára címmel. Vajon ma is így reagálnának az iskolák hasonló helyzetben? Bizonytalan vagyok, de nem vagyok meggyőződve arról, hogy ez elképzelhetetlen lenne.

Harminc év hosszú idő az emberi életben, és hosszú idő egy tudományos folyóirat életében is. Az egyik kérdéskör, amivel ezekben az évtizedekben - máig is - foglalkoztam, az európai, főként a magyarországi cigányság sorsának alakulása. Az EDU. ban először a Kisebbségek című számban 1993-ban írtam a cigányokról (Forray 1993) eltekintve az előző publikációtól -, és ugyanebben számban jelent meg német nyelven a magyarországi nemzetiségi oktatásról szóló, Hegedűs T. Andrással írott tanulmányunk is (Forray-Hegedüs 1993). Áttekintettük a népszámlálási adatokat, és figyelmeztettünk: hazai iskolai világunk változás előtt áll. E szám szerkesztése, a tanulmányok írása és megjelenése idejében még csak jogos követelménynek látszott és előkészítés alatt volt a cigány, roma népesség közösségi jogainak törvény szintű elismerése. 1993-ban jelent meg a nemzeti kisebbségekről szóló törvény, amely jogosultságot adott a cigányság történetének, kultúrájának az állami oktatásban való megjelenésére. (A cigány nyelvek, a romani és a beás oktatása csak az évtized végén törvénymódosításként fogalmazódott be.) Olyan lépés volt ez, amely nemcsak a magyarországi oktatásban jelentett újdonságot, hanem nemzetközi összefüggésben is. Az 1993-ban megjelent tanulmányomban azt a kérdést feszegettem, hogyan müködik a nemzetiségi-etnikai oktatás állami támogatása, megfogalmazva azt a sürgető követelményt, hogy a cigányság oktatása foglalja magában az anyanyelvi oktatást is. A cigányság középosztályosodása (Forray 2017) címmel publikált írásomban pedig azt a meggyőződésemet fejtettem ki, hogy e hátrányos helyzetű népcsoport felső rétegei beilleszkednek a többségi társadalom középosztályába.

\section{A történet}

Miért izgalmas kérdés ez számomra? Saját kutatásaim során - amelyeket Kozma Tamással végeztem a nyolcvanas években (Forray-Kozma 1992) - az a kérdés fogalmazódott meg, milyen különbségek vannak az ország egyes térségei között, és ezeket miként magyarázzák egyes jellegzetes lakossági csoportok, részint a magas iskolázottságúak, részint a lemaradók. Személyesen pedig egykori társasházi lakásunk környéke befolyásolt, ahol csinos családi házakban gazdag oláhcigány családok éltek, egyikükkel-másikukkal személyes kapcsolatba is kerültem. És persze mezőtúri gyermekkorom, cigány barátnőim, osztálytársaim, akik nagyjából úgy éltek, ahogyan mi, és a kisgyerekekkel érkező cigányasszonyok, akik nagyanyámhoz jártak valami apró adományért könyörögve. 
E népcsoportra irányuló tudományos kutatások már a hetvenes években elkezdődtek. A Kemény István vezette szociológiai kutatásban (Kemény 1996) részt vevők a nyolcvanas évekre erős politikai ellenzékké fejlődtek, és az új Magyarországon már valódi politikai hatalom birtokába kerültek. Fontos szerepet játszottak abban, hogy a törvényhozásban a cigányság érdekképviselete is megjelent, sőt hangsúlyossá vált. Ezekben a kutatásokban a cigányság az ország leghátrányosabb helyzetű lakossági csoportjaként fogalmazódott meg, amelynek felemelésére határozott lépések történtek. E csoport egyik jeles képviselője, Liskó Ilona szerkesztette az Educatio 1997 évi 1. számát Hátrányos helyzet címmel (Liskó 1997). A cím jelzi, hogy a "hátrányos helyzet” etnikai dimenzióban a cigányságot jelenti. Bár már csaknem két évtized elmúlt az írások megjelenése óta, ma is jogosnak látszik ez a megközelítés. Ám más aspektusok is érvényesek lehetnek.

Hegedűs T. Andrással folytatott kutatásainkban ezeket a „más aspektusokat” kerestük. Érdeklődésünk - amelyet személyes tapasztalataink is befolyásoltak - arra irányult, hogyan, milyen eszközökkel sikerül egyéneknek, családoknak és közösségeknek kitörni ezekből az eleve elrendeltnek tűnő helyzetekből (Forray-Hegedüs 1990). Némileg egyszerűsítve: míg az említett, ma már hagyományosnak mondható szociológiai „cigánykutatás” elsősorban a kudarcokra, mi a sikerekre helyeztük a hangsúlyt. Az iskolázás kérdése központi helyet foglal el akár a marginalizálódás, akár a kiemelkedés vizsgálatában. Tehát ha azt kérdezzük, miért kudarcosak a cigány fiatalok az oktatásban, vagy azt, hogy milyen körülmények között lehetnek sikeresek ugyanarról van szó. Van azonban egy jelentős különbség a vizsgálati módszerben. Az előbbi kérdésre választ keresők elsősorban kérdőíves-mintavételes kutatást használnak - értelemszerüen, hiszen a többségre kíváncsiak. Az utóbbi megközelítés az egyéni vagy kiscsoportos életútinterjút alkalmazza, mert az ilyen kutatót a kiemelkedő kisebbség érdekli. Azt vizsgálja, hogy valóban mindenkire érvényes-e az életkörülmények nyomorúsága, kik és milyen módon törnek ki ebből, és milyen életút vár rájuk. $\mathrm{S}$ ha a sikeres életutakat vesszük szemügyre, akkor elengedhetetlenek a helyi társadalom jellegzetességei is. Nem utolsósorban az, hogy mennyire nyitott, mennyire demokratikus egy közösség. Másként fogalmazva: mi nem klasszikus kutatókként közelítettük meg a cigányság társadalmi emelkedését, hanem kíváncsi emberekként. Akik azt szeretnék megtudni, hogyan élnek a cigányok, romák a mindennapokban, hogyan tudnak szabadulni nyomasztó életkörülményeiktől, miként tudnak sikeresen helytállni. Ez utóbbi kérdéseket ma a reziliencia fogalmával írjuk le.

\section{A származás vállalása}

Az 1993-ban született kisebbségi törvény egyik legvitatottabb pontja éppen a cigánysággal volt kapcsolatban. E vita eredményeképpen került a szövegbe a nemzeti kisebbségek elnevezés mellett az „etnikai” kifejezés is („nemzeti és etnikai kisebbségek”), hiszen a cigányság hivatalosan nem a "nemzetiség”, hanem az „etnikum” besorolást kapta. (A köznyelvben vagy egy évtizedig - néhol még ma is - „az etnikum” kifejezéssel utaltak a cigányságra.) Az 1997-es kormányzati cselekvési program - a korábbi tervezetekkel ellentétben - a cigányság speciális nyelvi és kulturális igényeinek kielégítését nem tartalmazza. A cigányság mint hátrányos helyzetű csoport felzárkóztatását fogalmazza meg, az átdolgozott NAT az „interkulturális oktatást” vette fel a lehetőségek 
közé. Ez lehetővé tette volna, hogy bizonyos tanulói csoportok a saját kultúrájukban is tájékozódhassanak. E célok tisztázása végül is elmaradt - ami megmaradt, az a költségvetési támogatás. Évek teltek el, amíg megfogalmazódott, hogy a „saját kultúrában tájékozódás" a romani és beás nyelveket és kultúrát jelenti. Ezen keresztül illeszthetők be a cigány kisebbségi iskolák a többi nemzetiségi iskola rendszerébe.

A nyelv azonban - akkor is és most is - problémát jelent. A kilencvenes évek végére formálódtak ki és kaptak törvényi elismerést a magyarországi cigányság által beszélt nyelvek (romani és beás), és az őket használó iskolai programok. (Azóta is tetemes nyelvvizsgáztatói munkát, bár nem egyszer előnyt is jelent az érintettek számára.) A már a rendszerváltás után bevezetett, és egyre szélesebb körűvé váló ösztöndíjazás a cigány, roma népesség számára is vonzó utat jelez, mivel támogatja az iskolázás és a magasabb fokú szakképzés elérését.

Egyre határozottabban rajzolódott ki kétféle lehetőség a cigányság felemelkedésére. Egyik a középosztállyá válás abban az értelemben, hogy beolvadnak a társadalom középrétegeibe. A középosztályi lét azonban asszimilációt feltételez, az etnikai jellemzők háttérbe szorulását. A magas igazgatási pozíciókba kerülők szempontjából közömbössé válhat mindaz, amit az illető személyes ügyeként hoz magával (nyelve, rokonsága, családjának, közösségének története stb.). Korábban ez volt az egyetlen út, hogy valaki etnikai eredete ellenére is - jelentős pozíciókat érhessen el. Ma azonban már lehetséges az az út is, hogy valaki a saját közösségi kultúrájának egyediségével lehessen a többségi társadalom tagja. Ez a törekvés célozza azokat a kulturális és politikai jogokat és szervezeti formákat, amelyekkel más népcsoportok már rendelkeznek Magyarországon. Ez a második út lehetővé, sőt szükségessé teszi a kulturális identitás (pl. nyelv) megőrzését is. Mindaddig azonban csak (üdvözlendő) politikai törekvés marad, amíg a mindennapokban azt látjuk, hogy a beás és a romani nyelvek a napi használatból kiszorulnak. Nem látjuk pontosan, hogy rangjuk, iskolai használatuk, egyáltalán: e nyelveknek jutó nagyobb társadalmi elismerés mennyiben járul hozzá a hagyományos cigány, roma kultúra megőrzéséhez. Annyi azonban világos, hogy a cigány, roma származás tagadása helyett - ami általános volt a középosztályba törekvők körében - mind általánosabb a származás nyílt vállalása, ezzel pedig az öntudat erősítése.

A nyelvhasználattól azonban függetleníteni lehet az etnikai öntudatot, bár a közéleti szerepvállaláshoz ma már láthatóan hozzátartozik. Beszél vagy sem valaki „cigányul”, attól még tekintheti magát cigánynak, romának. A hazánkban élő cigányság legnagyobb hányada egyébként is magyar anyanyelvü, tehát a nyelvi revitalizáció számukra egy „idegen" nyelv elsajátítását jelentené. És ami még fontosabb, hogy a magyarországi cigányság egy csoportja - a beások - élesen, egyértelmüen megkülönbözteti magát a romáktól (oláhcigányok). Ök nem fogják magukat az EU által javasolt egyetemes néven (roma) nevezni, és nem tekintik kötelezőnek egy másik cigány nyelv (lovári, romani) használatát - amint ezt Orsós Anna (2005) a hazai beás nyelv rendszerezője megállapította. Nem is szólva a nagyszámú nem roma cigány csoportról, amely a Balkánon és Európa számos országában él.

\section{Aluliskolázottság}

Ma is érvényes, hogy a cigányság a magyarországi népesség gyengén iskolázott, szegénységgel, nyomorral küzdő rétege. A teljes cigány, roma társadalomra kiterjedő empirikus 
kutatások (Kertesi Gábor és Kézdi Gábor [2009], Pénzes János és Pásztor István Zoltán [2018], Cserti Csapó Tibor [2011] munkái) megállapítják az extrémen alacsony iskolázottságot, gyenge foglalkoztatottságot, mindazokat az alapvetően fontos társadalmi tényezőket, amelyek a cigány, roma népességet a lakosság legrosszabb helyzetủ társadalmi rétegévé teszik. Ezen a drámaian tragikus összképen nem látszik elegendő változás a rendszerváltás óta eltelt három évtizedben. Bár nem lebecsülendő az sem, hogy legalább az általános iskolát a cigány, roma fiatalok túlnyomó része elvégzi, vagy közel áll ehhez. Az általános iskolai szinthez közelebb lépve ma az tünik fel, hogy a szabad iskolaválasztás jogával élve a helyi cigány lakosoknak a leggyengébb iskolák jutnak, azaz egyfajta szegregáció müködik ezen a szinten is. A rendszerváltáskor indított kezdeményezés, a szabad iskolaválasztás azzal a hátránnyal jár, hogy az iskolázottabb, gyermekeik jobb iskolázására törekedő családok - cigány családok is! - nem a helyben elérhető iskolába küldik a gyermeket, hanem választanak jobb iskolát a környéken. Ezt a szülői magatartást máig megfigyelhetjük, és esetenként súlyos problémákat okozhatnak.

Rendkívül nehéz tehát kitörni ebből a körből. Akinek mégis sikerült - a rezilienseknek, akik a középosztály felé törekszenek - azoknak, mint életútinterjúikból kitűnik, az adott iskola egy-egy tanára nyújtott segítséget. Az iskolai pályafutásukról beszélő középiskolás vagy egyetemista cigány fiatalok mindannyian név szerint emlékeznek meg óvónőikről, tanítóikról, tanáraikról, akik „felfedezték” őket, melléjük álltak, meglátogatták őket otthonukban, szüleikkel beszéltek, hogy egyengessék tanulási pályafutásukat. Sikeres cigány, roma fiatalokkal beszélgetve egészen más kép tárul a kutató elé a pedagógusokról, mint amit a sajtó dörgedelmeiből megismerhetünk.

A nevelőotthonokban, gyermekotthonokban élő gyerekek és fiatalok túlnyomó többsége ehhez a népcsoporthoz tartozik. Ha hátrányos helyzetü családból igen keveseknek nyílik út az iskolán keresztül a társadalom középső rétegeibe emelkedni, akkor a nevelőotthonban élők számára majdnem lehetetlen. Mégis nyomon követhető, hogy egyes fiatalok olyan támogatóra találnak, akik segítenek tehetségük kibontakozásában. Ezek azonban a véletlenek. A kilencvenes években még kevés civil szervezet müködött, amely segíteni akart és tudott e folyamatok gyorsításában, támogatásában. Ma azonban már civil és egyházi szervezetek sokaságára lehet támaszkodni. Jól megfigyelhető, hogy azt a személyes támogatást, ami az intézetben nevelkedőknek a legjobban hiányzik, a sikeres felnőtté válók elsősorban civil szervezetektől kapták.

A Pécsi Tudományegyetem volt az első, ahol a cigány, roma népesség történetével, kultúrájával, társadalmi-gazdasági problémáival foglalkozó tanszék létesült. Más felsőoktatási intézmények is próbálkoztak hasonló programokkal (közülük a Debreceni Egyetem Hajdúböszörményben müködő kara látszik tartósnak). Egy másik újdonság is a PTE-ről indult, az Oktatás és Társadalom Neveléstudományi doktori iskola egyik programja a cigánysággal kapcsolatos kutatását tűzte ki célként hazai és külföldi cigány, roma származású, és/vagy a kultúrájuk, sorsuk iránt elkötelezett hallgatók számára.

Az elmúlt évtizedek fontos kezdeményezése speciális szakkollégiumi hálózat szervezése a cigány, roma hallgatók, és általánosságban a leszakadt társadalmi rétegekből származó, súlyos anyagi helyzetben élő diákok számára. A pécsi egyetemen 2002-ben indult a ma is működő Wlisloczki Henrik Szakkollégium (Forray-Boros 2009), amely mintaként szolgált a ma már országszerte dinamikusan terjedő, külön kormányzati támogatással működő tehetséggondozási forma számára. Népszerű a diákság körében, és jelentősen hozzájárul a felsőoktatási végzettség elterjedéséhez a cigány népességben. 
A WHS ugyan állami fenntartású egyetemen szerveződött, ám a cigányok, romák egyetemi oktatását támogató szakkollégiumok dinamikus terjedését az egyházak kezdeményezték, és egyházi fenntartású intézményekben vált leggyakoribbá ez a támogatási forma. Hogy miért és hogyan történt ez, erről külön kutatásban lehetne érveket találni - az ilyen, általánosabb érvényű kutatások ma még hiányoznak.

\section{Cigány, roma csoportok és az iskolázás}

Ezekben az újdonságnak tekinthető tanulási folyamatokban nem a régi elit, a cigányzenészek családjai vesznek részt. A támogató programok tekintetbe veszik a család jövedelmét, szociális kormányzati támogatásban csak a legalacsonyabb jövedelmüek kapnak segítséget. A cigányzenészek gyermekei már hosszabb ideje továbbtanulnak a közép - és felsőoktatásban, diplomát szereznek, esetleg doktorálnak, és ennek megfelelő pozícióban dolgoznak. Nyilván ezzel is összefügg, hogy a fent hivatkozott szociológiai kutatások nem velük foglalkoznak, hanem csak a hátrányos helyzetủeket vizsgálják. Amikor cigányokról van szó, akkor a kutatás és a közbeszéd soha nem a zenészekre vonatkozik, rendszerint mint kivételekre sem hivatkoznak rájuk. Pedig ha ismerjük és elismerjük az öröklődő szegénység sújtotta generációk sorát, s ennek meghatározó voltát, nem hagyható figyelmen kívül az etnikai meghatározottságon belül sem a nemzedékeken át jellemző iskolázás, kivételezett társadalmi pozíciók befolyása. Nem azért, hogy az érintettek külön támogatásban részesüljenek, hanem az etnikai csoport pontosabb megismerése és leírása céljából.

Az intézményi tanulással kapcsolatban érdemes külön szólni a cigányság más, jellegzetes csoportjairól is. A pécsi kezdeményezések, nemcsak az egyetemi szak és szakkollégium, hanem előzménye, a Gandhi Gimnázium is fontos eleme a népcsoport iskolázásának (Forray 2013). A gimnáziumot a cigányság sorsáért érzett felelősség segített megalapítani, müködtetni a kilencvenes évek elején. (Egykori alapítói máig az egyetemen dolgoznak.) Azt se hagyjuk figyelmen kívül, hogy az első időszakban a dunántúli cigányság jellegzetes csoportjának tagjai, a beások népesítették be, bár mai tanulói között az ország minden tájáról találhatunk képviselőt. Nehéz nem arra gondolni, hogy ez a cigány csoport - akár hagyományai, akár az iskolai, müvelődési lehetőségek miatt - integráltabb, alkalmasint iskolázottabb is, mint más csoportok.

$\mathrm{A} z$ oláhcigányok, a romák, akik a cigányság számban kisebb és a tradicionális elit rétegébe tartoznak, kevésbé tűntek és tűnnek motiváltnak a romológia szak elvégzésében. Ha továbbtanulnak és nem családjaik kereskedelmi tevékenységét követik, inkább más, hagyományosabb felsőfokú képzést választanak.

A magyarországi cigányság legnagyobb hányadát a magyarcigányok (romungrók) teszik ki. Akik és amikor a cigány családok elesettségéről, nyomoráról írnak, elsősorban rájuk, a legnagyobb létszámú népességre gondolnak és hivatkoznak. A dokumentumok, amelyeket Nagy Pál (pl. 1999) elemez, megerősítik évszázados magyarországi életüket, magyar nyelvüket. Van azonban a szerzőnek olyan teóriája is, hogy a cigányság egyes csoportjait részben az eredeti jobbágytelkek lakói képezték, tehát többé vagy kevésbé jelentős hányaduk eredetileg nem cigány, roma etnikumú. E (jól dokumentált) feltételezésből következhet akár az is, hogy a ma magyarcigánynak értelmezett közösség többé vagy kevésbé jelentős hányada etnikai eredetét tekintve nem tartozik ebbe a népcsoportba, egykori anyanyelvük sem valamelyik cigány nyelvjárás. Ha ezek az isko- 
lák romani nyelvü programot hirdetnek, valósítanak meg, akkor - legalábbis a nyelvhasználat területén - nem az eredeti anyanyelv feléledését szolgálják. Inkább divatnak engedelmeskednek, vagy a szokásosnál nagyobb állami támogatást szeretnének elérni.

A cigány, roma lakosság legnagyobb tömegben az ország keleti és északkeleti területein él, sok ezren nyomorban, iskolázatlanul, képzetlenül. Ám azt is hangsúlyozni kell, hogy jelentős számban kerülnek ki közülük jól képzett munkások, érettségizettek és diplomások, akik a gazdaság és közigazgatás több pontján megtalálhatók. Ahogyan ez magától értetődőnek tekinthető, szervezeteik müködése és munkatevékenységük nem ezekben a térségekben történik. Értelemszerủen a cigányságot segítő, az iskolázást és társadalmi mobilitást előmozdítani szándékozó civil és állami programok nagy hányada ma ebben a térségben szerveződik.

\section{Hátrányból előnyt}

A kilencvenes évek végén alakult meg az országos cigány önkormányzat, akkor még jelentős várakozást keltve. Elnöke, jelentősebb tagjai Jász-Nagykun-Szolnok megye falvaiból kerültek ki. Az önkormányzat működésének első húsz évében jelentős kezdeményezés volt a Gandhi Gimnázium mintájára szervezett középiskola Szolnokon, ahol a város és a környékbeli falvak sok cigány és szegény sorsú nem cigány fiatalja szerzett szakképzettséget és érettségit. Sajnos az iskola (legalábbis számomra) ismeretlen, de botrányos körülmények között megszűnt.

Valójában máig sincs konszenzus arról, érdemes-e a többi nemzetiségi iskola mintájára a cigány, roma népesség számára is önálló oktatási intézményt szervezni. A Gandhi Gimnázium évtizedek óta sikeresnek számít - bár a legutóbbi években kevesebb jelentkezővel múködik -, a hasonló próbálkozások valamilyen okból kudarcba fulladtak. Azt is szem előtt kell tartani, hogy a gimnázium más programot kínál, mint a mindenkinek kötelező általános iskola, legyen az 4, 6 vagy 8 osztályos. Ehelyett talán az a megfelelő megoldás, ha önkéntes nemzetiségi programot szerveznek azokban az iskolákban, ahol a diákság számára ez kívánatosnak látszik. Látható azonban, hogy a tisztán „cigány nemzetiségi" iskola nem eléggé vonzó a diákok és családjaik számára, de a kormányprogram sem szorgalmazza ezt az európai uniós programnak megfelelően. Ehelyett a társadalmi hátrányok leküzdését tartja fő célnak roma és nem roma tanulók számára egyaránt.

Amint az is jól látható, hogy a törekvő cigány családok gyermekeiket nem a „számukra” létrehozott iskolákba irányítják, hanem színvonalas, nemegyszer egyházi fenntartású iskolákba íratják be. A középosztályosodás növekvő tendenciáját éppen az ilyen társadalmi rétegekre vonatkozóan figyeltük meg és fogalmaztuk meg Kozma Tamással a témában írott tanulmányainkban (Forray-Kozma 2013, 2020). A cigányság helyzetével, kilátásaival foglalkozó kutatók ma is az extrémen alacsony szintű iskolázottságot hangsúlyozzák a teljes roma népességben, mi pedig arra hívjuk fel a figyelmet, hogy növekszik a magasabban iskolázottak hányada. Ez is olyan folyamatnak látszik, amely egyre inkább kiterjed. Egykor csak a muzsikus cigányok rétege volt az, amely érzékelhetően törekszik iskolázni, sőt diplomához juttatni gyermekeit, ma már mindegyik cigány, roma társadalmi rétegben találunk párhuzamokat. Nehéz nem a parasztságra gondolnunk, amely a második világháború kezdetén jutott olyan támogató programokhoz, amelyek magasabb iskolázottság elérését tűzték ki célul - a népi kollégiumi mozgalom 
a szocialista rendszerváltásig sok száz fiatalt juttatott magas iskolázottsághoz. Az iskolázás mai kiterjedése a még nagy arányban aluliskolázott cigány lakosságot juttathatja hasonló eredményhez. Ehhez azonban - ugyanúgy, ahogyan sok évtizede az akkori parasztságnak - ennek a népességnek is támogatásra van szüksége.

A pozitívumok hangsúlyozása nem jelenti azt, hogy ne vegyük tudomásul a máig tömegesen aluliskolázott, munkanélküli cigány népességet. Ám látni kell azt is, hogy a gyerekek és fiatalok körében olyan folyamatok indultak meg, amelyeknek eredményességében okkal bízhatunk. Civil szervezetek kezdeményezései mellett az utóbbi néhány évben kormányzati támogatást kapott a Magyar Máltai Szeretetszolgálat is, amely már hosszabb ideje szervez roma felzárkóztató programokat.

A legutóbbi Kozma Tamással írott tanulmányunkban (Forray-Kozma 2020) azt vizsgáltuk, hogyan oldották meg a politikai dilemmákat a helyi társadalom érintett rétegei és a segítő / segítséget kínáló szervezetek. A Tiszabő és Tiszabura feszítő társadalmi-gazdasági problémáit orvosolni próbáló Máltai Szeretetszolgálat tevékenységét vetettük össze a Gyöngyöspata hasonló gondjait megoldani szándékozó Esélyt a Hátrányos Helyzetű Gyerekeknek Alapítványéval. A kétféle megközelítés fó célját tekintve hasonló: mind a kettő a társadalom (iskola) nyitottságát, a cigányság befogadását szeretné elérni. Az egyik, a jogvédő, az Amerikából ismert polgárjogi mozgalom eszköztárát alkalmazza, a másik pedig a befogadás szükségességét és annak segítését tartja fontosnak. Mindkét akció elérte a célját: a gyöngyöspatai cigányok jelentős kártérítést kaptak a kirekesztés jóvátételeként, a máltaiak munkahelyeket teremtettek, óvodát létesítettek, iskolai fejlesztő programokat indítottak be. Hogy melyik az eredményesebb megoldás, az csak évek múltán fog eldőlni.

A cigány, roma népességgel kapcsolatos összes társadalompolitikai kérdést ebben a rövid írásban nem tudtam áttekinteni. Csak azokat a problémákat vizsgáltam, amelyekre magam az Educatio hasábjain az elmúlt harminc évben reflektáltam. Közülük mint vezérfonalat szeretném kiemelni a cigány társadalom szerkezeti átalakulását, és egy cigány, roma középosztály kiemelkedését. A társadalompolitikai problémákat érdemes tehát új oldalról, a cigány, roma társadalom átalakulásának nehézségeként megragadni. Az elmúlt harminc év a cigány, roma társadalom változásának története, benne egy új középosztály kialakulásának minden jajával-bajával. Kezdettől reméltem, hogy így lesz. Harminc év után már tudom. Bízom benne.

\section{IRODALOM}

Cserti Csapó T. (2011) A cigány népesség a társadalmi-gazdasági térszerkezetben. Pécs, PTE BTK Oktatáskutató Központ, Virágmandula Kft.

Forray R. K. (1992) A szabadság piaci ára. Educatio, Vol. 1. No. 2.pp. 259-260.

Forray R. K. (1993) A nemzetiségi-etnikai oktatás állami támogatása. Educatio, Vol. 2. No. 2. pp. 221-234.

Forray, R. K. (2013) Colleges for Roma in Higher Education. Hungarian Educational Research Journal, Vol. 3. No. 3. pp. 1-8. 
Forray R. K. (2017) A cigányság középosztályosodása. Educatio, Vol. 25. No. 4. pp. 581590.

Forray R. K. \& Boros J. (2009) A cigány, roma tehetséggondozás intézményei. Educatio, Vol. 17. No. 2. pp. 192-203.

Forray R. K. \& Hegedüs T. A. (1990) A cigány etnikum újjászületöben. Budapest, Akadémiai Kiadó.

Forray, R. K. \& Hegedús, T. A. (1993) Schulpolitik und nationale Minderheiten. Educatio, Vol. 2. No. 2. pp. 245-252.

Forray R. K. \& Kozma T. (1992) Társadalmi tér és oktatási rendszer. Budapest, Akadémiai Kiadó.

Forray R. K. \& Kozma T. (2010) Társadalmi egyenlőség vagy kulturális identitás? Képzés és Gyakorlat, Vol. 8. No. 2.pp. 3-21.

Forray R. K. \& Kozma T. (2013) Menekülés az iskolától. Educatio, Vol. 21. No. 1. pp. 23-34.

Forray R. K. \& Kozma T. (2020) Befogadók vagy jogvédők? Educatio, Vol. 29. No. 3. pp. 339-349.

Kemény I. (1996) A romák és az iskola. Educatio, Vol. 5. No. 1. pp. 71-83.

Kertesi G. \& Kézdi G. (2009) Általános iskolai szegregáció Magyarországon az ezredforduló után. Közgazdasági Szemle, 2009. november (pp. 959-1000.) https://www.econstor. eu/handle/10419/108447 [Letöltve: 2021. 09. 10.]

Liskó I. (1997, szerk.) Hátrányos helyzet. Educatio, Vol. 6. No. 1. (tematikus szám)

NaGy P. (1999) „Kicsinségemben elszakattam”. Educatio, Vol. 8. No. 3. pp. 320-338.

Orsós A. (2005) A nyelvi másság dimenziói. Educatio, Vol. 14. No. 1. pp. 186-194.

Pénzes J., Tátrai P. \& Pásztor I. Z. (2018) A roma népesség területi megoszlásának változása Magyarországon az elmúlt évtizedekben. Területi Statisztika, Vol. 58. No. 1. pp. 3-26.

A cikk a Creative Commons Attribution 4.0 International License (https://creativecommons.org/licenses/ by/4.0/) feltételei szerint publikált Open Access közlemény, melynek szellemében a cikk bármilyen médiumban szabadon felhasználható, megosztható és újraközölhető, feltéve, hogy az eredeti szerző és a közlés helye, illetve a CC License linkje és az esetlegesen végrehajtott módosítások feltüntetésre kerülnek. (SID_1) 